\title{
Desain Self-Propelled Fishing Barge Berbahan Fiberglass Reinforced Polymer (FRP) Ramah Lingkungan Sebagai Alternatif Kapal Kayu Tradisional di Perairan Kepulauan Seribu
}

\author{
Kevin Hermanto dan Hesty Anita Kurniawati \\ Departemen Teknik Perkapalan, Fakultas Teknologi Kelautan, Institut Teknologi Sepuluh Nopember \\ (ITS) \\ e-mail: tita@na.its.ac.id
}

\begin{abstract}
Abstrak-Mayoritas masyarakat daerah pesisir Ibukota DKI Jakarta mengandalkan laut sebagai sumber mata pencahariannya. Banyak dari mereka yang berlayar menggunakan kapal milik perusahaan ataupun berlayar menggunakan kapal sendiri. Dengan kondisi kapal yang tersedia di lapangan saat ini berupa kapal kayu tradisional, maka Jurnal ini bermaksud memberikan desain alternatif berupa barge berbahan fiberglass yang memiliki kelebihan spesifik dibandingkan dengan kapal kayu tradisional. Jurnal ini tidak bermaksud membenturkan desain alternatif ini dengan kapal kayu tradisional. Masing-masing memiliki kelebihan dan kekurangannya, sehingga konsumen dipersilahkan memilih salah satu sesuai dengan kebutuhannya. Penentuan payload Bagan Apung ini adalah jumlah produksi ikan per tahun di DKI Jakarta yang didapat dari Badan Pusat Statistik. Lalu data tahunan tersebut dikonversi menjadi data harian, sehingga payload yang digunakan pada Bagan Apung adalah jumlah produksi ikan DKI Jakarta tiap harinya. Setelah itu dilakukan perhitungan perkiraan beban awal untuk membuat model Bagan Apung awal. Setelah itu dilakukan perhitungan teknis, yakni koefisien, hambatan, propulsi dan daya mesin, berat, titik berat, freeboard, trim, dan stabilitas. Setelah dilakukan perhitungan teknis, selanjutnya dilakukan koreksi pada model Bagan Apung untuk memenuhi persyaratan teknis yang telah dihitung, lalu memodelkan ulang Bagan Apung sesuai dengan persyaratan teknis. Ukuran utama yang didapat adalah $\mathrm{Lpp}=12.7 \mathrm{~m}, \mathrm{~B}=\mathbf{2 . 7}$ $\mathrm{m}, \mathrm{H}=\mathbf{2} \mathrm{m}, \mathrm{T}=\mathbf{0 . 6 6} \mathrm{m}$. Tinggi freeboard minimum sebesar 300 mm, sedangkan freeboard sebenarnya adalah $1.34 \mathrm{~m}$. Kondisi stabilitas Bagan Apung ini memenuhi kriteria Intact Stability (IS) Code untuk Fishing Vessel. Perhitungan ekonomi yang dilakukan adalah biaya pembangunan, biaya operasional, revenue, kelayakan investasi, dan Breakeven Point.
\end{abstract}

Kata Kunci-Bagan Apung, Fiberglass, Kapal Ikan, Kepulauan Seribu, Jakarta, Tongkang

\section{PENDAHULUAN}

$\mathrm{P}$ ERAIRAN Kepulauan Seribu telah menjadi salah satu tempat mata pencaharian utama bagi nelayan di Jakarta dan Kepulauan Seribu. Pada perairan ini, potensi hasil lautnya beranekaragam mulai dari ikan baronang, ikan tenggiri, ikan kakap merah, ikan kerapu, dan masih banyak lagi sehingga aktivitas nelayan hendaknya didukung dengan memberikan desain alternatif kapal yang lebih baik dan nyaman untuk melakukan pekerjaannya.
Potensi perikanan di Kepulauan Seribu masih memperlihatkan tren yang menjanjikan bagi nelayan pesisir DKI Jakarta. Tercatat dari tahun 2010 hingga tahun 2015 menunjukkan hasil produksi yang terus meningkat. Dapat diperkirakan di masa yang akan datang akan dibutuhkan lebih banyak kapal ikan untuk memanen hasil laut di perairan kepulauan Seribu. Sebab data yang penulis miliki sendiri hanya sebatas produksi ikan yang dimiliki oleh Tempat Pelelangan Ikan (TPI), belum data produksi ikan yang dijual di luar TPI.

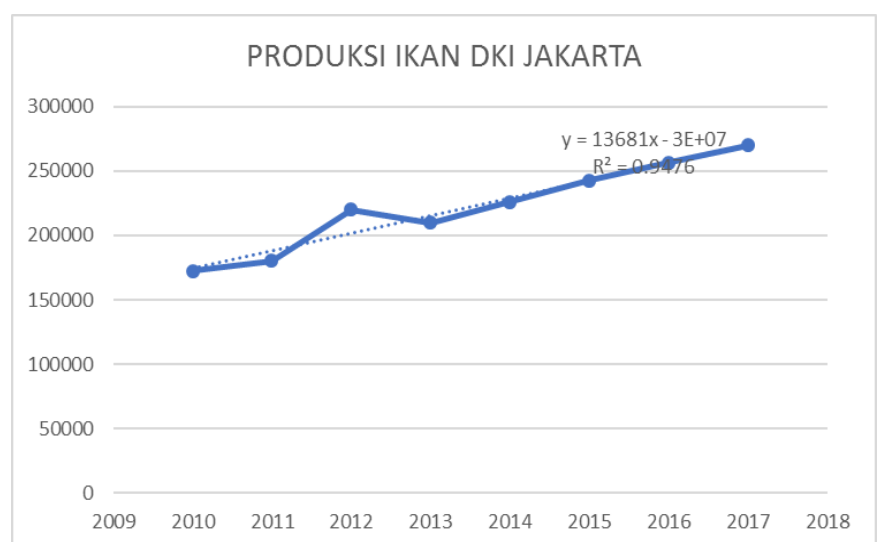

Gambar 1. Grafik permintaan ikan di DKI Jakarta

Self Propelled Fishing Barge (SPFB) ini dimaksudkan untuk memberikan pilihan bagi konsumen dalam hal ini nelayan, apakah memilih kapal kayu tradisional atau memilih Self Propelled Fishing Barge (SPFB) ini. Tentu saja masing masing memiliki kelebihan dan kekurangannya. Sehingga pilihan dikembalikan lagi ke konsumen untuk memilih desain bagan apung yang sesuai dengan kondisi finansial dan kebutuhan mereka. Beberapa kelebihan yang ditawarkan SPFB berbahan fiberglass ini yakni, bebas biaya perawatan lambung, ruangan yang lebih lapang, biaya pembangunan lambung yang relatif murah, ramah lingkungan, dan lambung timbul yang relatif rendah untuk mempermudah pekerjaan nelayan. 


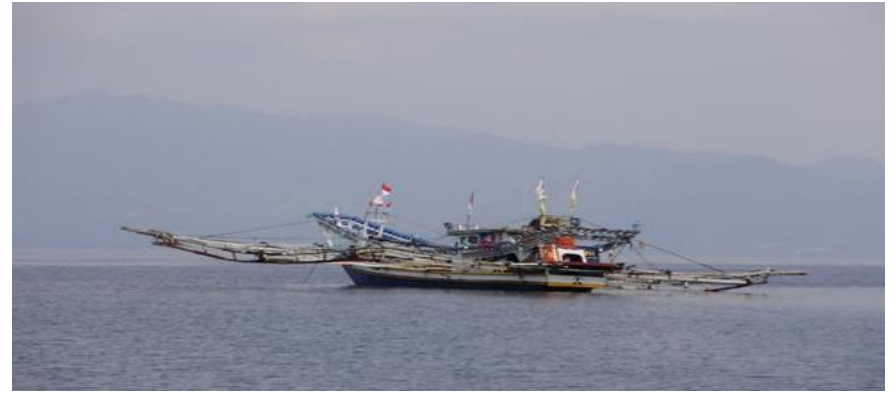

Gambar 2. Bagan apung tradisional

Untuk tambahan, nantinya kapal ikan berbentuk tongkang ini dapat juga dijadikan tempat wisata, yakni untuk menjadi spot memancing bagi wisatawan yang gemar memancing. Bagi wisatawan yang gemar memancing dapat memanfaatkan kapal ini untuk ikut serta memancing ikan dan kemudian membelinya dari nelayan dari kapal ini. Analisis teknikal akan diperlukan untuk menghitung stabilitas dan freeboard kapal ini, serta peninjauan terhadap teknis operasional kapal bagan akan diperlukan sebagai dasar untuk memulai perancangan kapal bagan berbentuk tongkang ini.

\section{TINJAUAN PUSTAKA}

\section{A. Barge}

Barge atau tongkang adalah kapal dengan lambung datar, baik memiliki sistem penggerak ataupun tidak, yang digunakan untuk mengangkut muatan di kanal ataupun sungai. Contoh muatan yang biasa diangkut oleh tongkang adalah pasir ataupun batubara, tergantung kebutuhan. Tongkang adalah salah satu variant dari kapal kontainer yang sudah diisi muatan sebelumnya [1].

\section{B. Kapal Penangkap Ikan}

Kapal penangkap ikan adalah perahu atau kapal yang digunakan untuk menangkap ikan di laut, danau, atau sungai. Berbagai jenis kapal laut digunakan dalam penangkapan ikan komersial, olahraga, maupun rekreasi [2].

Berdasarkan FAO, pada tahun 2004 terdapat setidaknya empat juta kapal penangkap ikan komersial. Sekitar 1,3 juta merupakan kapal yang memiliki geladak. Hampir semua kapal bergeladak ini sudah termekanisasi, dan 40 ribu diantaranya berbobot lebih dari 100 ton. Sekitar dua per tiga dari empat juta kapal tersebut merupakan perahu penangkap ikan tradisional dengan berbagai tipe, digerakkan dengan layar dan dayung. Perahu tersebut biasanya digunakan oleh nelayan tradisional. Sulit untuk menentukan berapa jumlah perahu penangkap ikan rekreasi. Ukuran perahu tersebut sangat bervariasi, selain tujuan penggunaannya tidak selalu untuk menangkap ikan.

Sebelum tahun 1950an, hanya ada sedikit standarisasi kapal penangkap ikan. Desain dapat bervariasi antar pelabuhan dan galangan kapal. Sebelumnya perahu dibuat dari kayu. Namun karena biaya perawatan tinggi dan dengan perkembangan teknologi material, baja, fiberglass, dan serat karbon lebih banyak digunakan. Lamanya pembuatan perahu penangkap ikan tradisional bervariasi antara enam bulan hingga satu tahun. Berikut adalah jenis - jenis kapal penangkap ikan:

\section{a. Perahu Nelayan Tradisional}

Nelayan tradisional melakukan penangkapan ikan skala kecil secara subsisten maupun komersial, umumnya dilakukan oleh penghuni pantai dan kelompok etnik tertentu menggunakan metode penangkapan ikan dan perahu tradisional (Wikipedia, 2010).

Sejumlah besar kapal dan perahu nelayan tradisional masih digunakan di negara berkembang dengan garis pantai perikanan produktif yang panjang. Indonesia dilaporkan memiliki sekitar 700 ribu perahu penangkapan ikan, dengan seperempatnya berupa kano dan setengahnya tidak memiliki mesin.

Filipina memiliki kurang lebih jumlah yang sama, dengan sebagian merupakan perahu dengan lambung yang sempit dan memiliki "sayap". Perahu ini disebut dengan jukung, atau dalam Bahasa Filipina disebut banca [3].

\section{b. Kapal atau Perahu Rekreasi}

Kapal penangkap ikan rekreasi hanya digunakan sebagai sarana rekreasi atau olahraga, bukan untuk bertahan hidup dan komersial. Istilah ini tergolong cair karena apapun yang mengapung dan orang di atasnya ingin menangkap ikan dengan tujuan selain komersial dan subsisten dapat disebut dengan kapal penangkap ikan rekreasi. Jenisnya bervariasi mulai dari rakit, kano, kayak, hingga kapal jelajah (cruise yacht) dengan geladak besar dan kabin mewah. Kapal yang sejak awal bukan untuk penangkapan ikan rekreasi (misal untuk perjalanan atau kargo) pun dapat berubah seketika menjadi kapal penangkapan ikan rekreasi.

Perburuan ikan (big game fishing) menjadi sebuah olahraga resmi sejak ditemukannya kapal motor. Charles Frederick Holder, seorang pakar biologi kelautan ditengarai sebagai pencetus olahraga ini pada tahun 1898. Kapal yang dibangun khusus untuk big game fishing muncul segera setelah itu [3].

\section{c. Kapal Komersial}

Secara umum, kapal penangkap ikan komersial dapat diklasifikasikan berdasarkan desain, jenis hewan laut yang ditangkap, metode penangkapan ikan yang digunakan, dan asalnya. Berdasarkan FAO, kapal penangkap ikan yang beroperasi di seluruh dunia mencapai empat juta kapal, dengan 1,3 juta merupakan kapal yang dilengkapi dengan geladak. Hampir seluruh kapal bergeladak memiiki mesin, dan $86 \%$ nya berlabuh di Asia [3]. Kapal penangkap ikan komersial secara umum dapat dibagi menjadi:

\section{a. Trawler}

Trawler adalah kapal penangkap ikan yang digunakan untuk menarik jaring sepanjang alur pelayaran untuk menangkap ikan dalam jumlah besar sekaligus [3].

\section{b. Seiner}

Seiner adalah kapal yang menggunakan jaring penangkap ikan yang lebar untuk mengurung ikan. Umumnya digunakan untuk menangkap ikan yang berenang dekat dengan permukaan, namun telah ada desain pukat yang dapat menangkap ikan laut dalam [3]. 


\section{c. Longliner}

Longliner adalah kapal yang menggunakan satu atau lebih tali atau kail dengan rangkaian umpan dan kait. Panjang dan jumlah kail, umpan, dan kait bervariasi tergantung pada ukuran kapal, jumlah kru, dan level mekanisasi kapal. Jenis ikan yang ditangkap pun bergantung pada umpan yang digunakan. Kail dapat diulur dan ditarik menggunakan drum berputar yang besar, yang biasanya diletakkan di buritan kapal. Kapal rawai ukuran kecil dapat menggunakan tangan untuk mengulur dan menarik kail. Kecepatan kapal menentukan seberapa dalam dan seberapa jauh jangkauan kail.

Troller adalah salah satu jenis longliner dengan kail yang tergantung di sisi kapal yang bergerak. Squid jigger menggunakan kail yang panjang untuk menangkap cumi-cumi. Squid jigger biasanya dilengkapi dengan cahaya lampu yang terang untuk menarik perhatian cumi-cumi [3].

\section{Fiberglass (FRP) Ramah Lingkungan}

Fiber-Reinforced Plastic atau fiberglass adalah material komposit yang terdiri atas Polymer yang diperkuat oleh serat kaca. Polymer biasanya berupa epoxy, vinylester or polyester thermosetting plastic, dan phenol formaldehyde resins.

Berdasarkan data berupa Material Safety Data Sheet, material fiberglass tidak bersifat beracun terhadap lingkungan. Seiring dengan berkembangnya teknologi, fiberglass pun sudah dapat didaur ulang, namun praktiknya belum begitu luas, dikarenakan mayoritas benda-benda yang dibuat dari fiberglass, biasanya memiliki umur pakai yang lumayan lama. Daur ulang dilakukan dengan cara yang hampir mirip dengan plastik, yaitu dihancurkan sampai menjadi bentuk serbukserbuk, lalu nantinya serbuk-serbuk ini dapat dicetak lagi menjadi benda-benda lainnya.

\section{SECTION XI- TOXICOLOGICAL PROPERTIES}

$\begin{array}{llll}\text { Route of Entry: } & \text { Skin contact }[\mathrm{X}] & \text { Skin absorption }[]^{-} & \text {Eye contact }[\mathrm{X}] \\ & \text { Inhalation }[\mathrm{X}] & \text { Ingestion }\end{array}$

$$
\text { Inhalation }[\mathrm{X}] \text { Ingestion }[\mathrm{X}]
$$

\section{EFFECTS OF ACUTE EXPOSURE:}

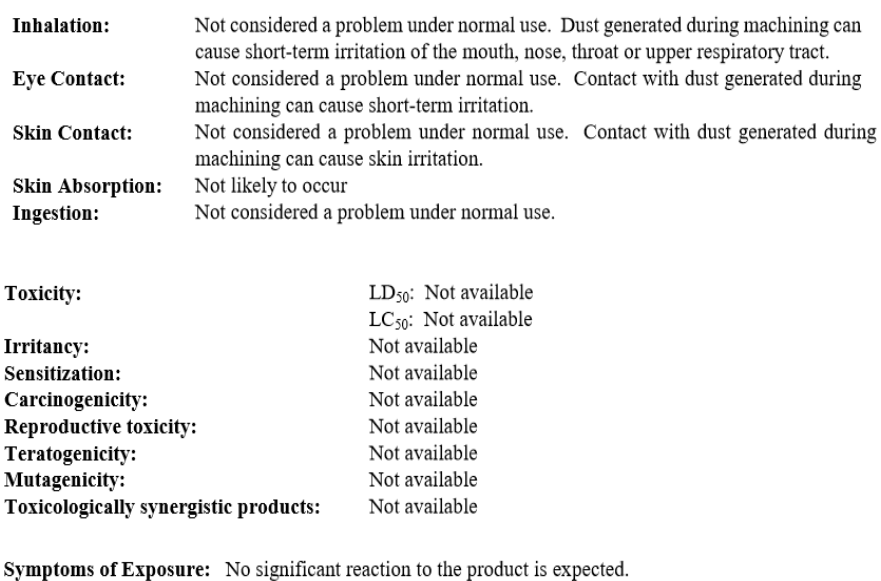

\section{SECTION XII - ECOLOGICAL INFO}

$\begin{array}{ll}\text { Toxicity: } & \text { No information available. } \\ \text { Biodegradation and Elimination: } & \text { Not readily biodegradable. } \\ \text { Bioaccumulation Potential: } & \text { No information available. } \\ \text { Mobility: } & \text { No information available. } \\ \text { Additional Information: } & \text { No additional information available. } \\ \text { Gambar 3. Penggalan dari Fiberglass Safety Data Sheet }\end{array}$

\section{METEDOLOGI PENELITIAN}

\section{A. Diagram Alir}

Tahapan dari metodologi penelitian yang digunakan digambarkan pada diagram alir di bawah :

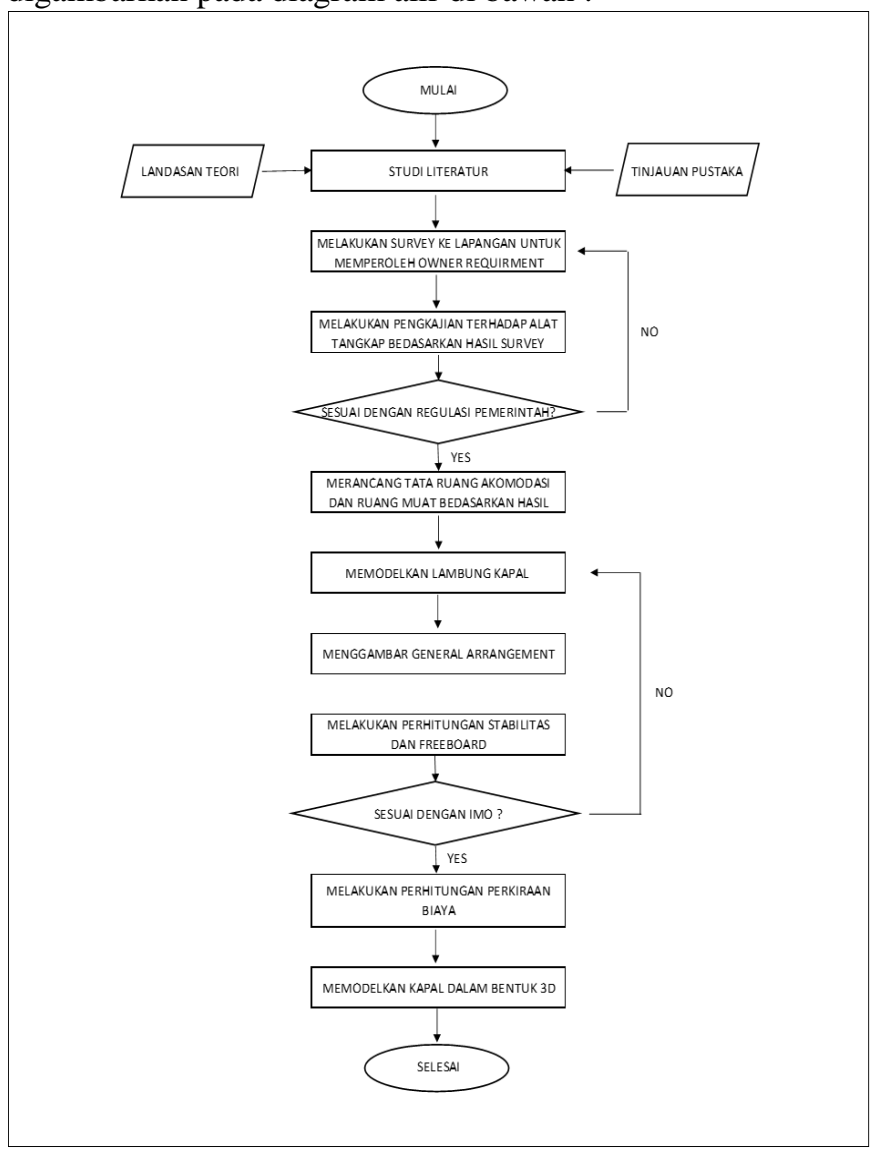

Gambar 4. Diagram alir desain SPFB

\section{PERHITUNGAN TEKNIS SELF-PROPELLED FISHING BARGE}

\section{A. Penentuan Payload}

Penentuan payload dari Self-Propelled Fishing Barge berdasarkan jumlah produksi ikan di Tempat Pelelangan Ikan (TPI) yang ada di Jakarta dari tahun 2010 sampai dengan tahun 2016 dan data jumlah bagan apung yang beroperasi di Jakarta dari tahun 2008 sampai dengan tahun 2016. Dari data yang didapatkan, kemudian dihitung payload dari jumlah produksi ikan dari bagan apung yang sudah beroperasi di lapangan. Lalu untuk mendukung data sekunder, dilakukan wawancara dengan nelayan setempat untuk mengetahui apakah data sekunder yang didapat sudah tepat.

Inti dari hasil wawancara yang dilakukan adalah tangkapan per malam berkisar antara 0.2 ton hingga 2 ton, sehingga dapat disimpulkan olahan data untuk payload yang dilakukan pada sub Bab IV.2 cukup akurat, yakni 0.7 ton. Selanjutnya, diketahui dari hasil wawancara apabila kapal yang digunakan untuk bagan apung ini tidak memerlukan ruang muat berupa palkah, melainkan ruang muat berupa drum-drum plastik. Lalu didapat juga informasi mengenai hasil tangkapan yang sering didapa. Untuk hasil wawancara lebih detil dapat dilihat pada lampiran B. 
Data jumlah produksi ikan di TPI ini didapatkan dari website Badan Pusat Statistik (BPS). Data yang tersedia adalah dari tahun 2010 sampai dengan tahun 2014, sehingga dilakukan forecasting untuk tahun 2016 dan tahun 2017. Data jumlah bagan apung yang tersedia di DKI Jakarta tersedia dari tahun 2004 sampai dengan tahun 2008, sehingga dilakukan forecasting sampai dengan tahun 2017.

Dari kedua data di atas, dapat diperkirakan kapasitas muatan tiap bagan apung yang beroperasi di Jakarta. Lalu setelah pengolahan data selesai, dilakukan wawancara terhadap nelayan setempat untuk membandingkan hasil pengolahan data dengan hasil wawancara. Payload yang didapat setelah dilakukan pengolahan data adalah sebesar 0.7 ton.

\section{B. Permodelan Awal SPFB}

Setelah didapatkan hasil nilai payload, selanjutnya dilakukan perhitungan perkiraan berat kapal awal secara keseluruhan, mulai dari payload, berat lambung perkiraan (dimodelkan terlebih dahulu), berat bahan bakar, berat air tawar, dan lain - lain. Perkiraan berat awal ini digunakan untuk membuat model awal di Maxsurf untuk merekayasa ukuran utama hingga memenuhi rasio ukuran utama yang disyaratkan. Perhitungan estimasi berat awal kapal adalah sebesar 14.26 ton. Sehingga, selanjutnya dilakukan permodelan di Maxsurf Modeller sampai mendapatkan displacement mendekati estimasi berat kapal awal.

\section{Perhitungan Hambatan}

Perhitungan hambatan SPFB menggunakan metode hambatan dari Korean Registry of Shipping (KR) dimana perhitungan dari metode ini dianggap paling sesuai dengan kondisi pelayaran dan bentuk lambung SPFB. Berikut akan dipaparkan hasil perhitungan menggunakan metode hambatan dari Korean Registry of Shipping [4].

1. Frictional Resistance

Di mana,

$$
R_{f}=0,000136 . \mathrm{F} 1 . \mathrm{A} 1 . \mathrm{V}^{2}
$$

$\mathrm{F}_{1}=0.8 ;$ KR 'Rules for the Towing Survey of Barges and Tugboats' page 6

$\mathrm{A}_{1}=$ Wetted Surface Area below Waterline

$\mathrm{V}=$ Towing velocity

$\mathrm{R}_{f}=0,000136 \cdot 0,8 \cdot 36,441 \cdot 5 \cdot 1442$

$=0.104911018$ ton

$=104.911018 \mathrm{~kg}$

$=1029.177087 \mathrm{~N}$

$=1.029177087 \mathrm{kN}$

2. Wave Making Resistance

$$
\mathrm{R}_{\mathrm{w}}=0,014 \cdot \mathrm{C} \cdot \mathrm{F}_{2} \cdot \mathrm{A}_{2} \cdot \mathrm{V}^{2}
$$

Di mana,

$\mathrm{C}=$ Resistance Coefficient of Rough Sea Condition, 1.2

$\mathrm{A}_{2}=$ Hull Cross sectional Area below Waterline $=1.62 \mathrm{~m} 2$

$\mathrm{V}=$ Towing velocity

$\mathrm{F}_{2} \quad=$ Bow Shape Coefficient ; table II.4

$\mathrm{R}_{\mathrm{w}}=0,014 \cdot 1,2 \cdot(0,3 / 0,5) \cdot 1,62 \cdot 5 \cdot 1442$

$=0.432093235$ ton

$=4.238834631 \mathrm{Kn}$
3. Air Resistance

Di mana,

$$
R_{a}=0,0000195 \cdot C_{s} \cdot C_{H} \cdot A_{3} \cdot(V w+V)^{2}
$$

A $=$ Total Cross Sectional Area Exposed to Wind above Waterline $=8.64 \mathrm{~m} 2$

$\mathrm{V}=$ Towing Velocity

$\mathrm{C}_{\mathrm{S}}=$ Shape Coefficient of Hull Surface Facing the Wind

$\mathrm{C}_{\mathrm{H}}=$ Koefisien tinggi dari garis air ke pusat luasan yang terpapar angin

$\mathrm{R}_{\mathrm{a}}=0,0000195 \cdot \mathrm{Cs} \cdot \mathrm{CH} \cdot \mathrm{A} 3 \cdot(\mathrm{Vw}+\mathrm{V}) 2$

$=0.371064547$ ton

$=3.640143208 \mathrm{kN}$

4. Added Resistance

$\mathrm{R}_{\text {added }}=$ sesuai tabel dari $\mathrm{KR}$.

5. Total Resistance

$$
\begin{aligned}
& =1 \text { ton } \\
& =9.81 \mathrm{kN}
\end{aligned}
$$

$$
\begin{aligned}
\mathrm{R}_{\text {total }} & =R_{f}+R_{w}+R_{a}+R_{\text {added }} \\
& =1.029+4.2388+3.64+9.81 \\
& =18.71815493 \mathrm{kN}
\end{aligned}
$$

Setelah didapat hambatan total di atas, maka selanjutnya dilakukan perhitungan propulsi dan daya mesin yang dibutuhkan SPFB untuk dapat mencapai kecepatan dinas yang diinginkan.

\section{Pemilihan Mesin}

Setelah dilakukan perhitungan hambatan, selanjutnya dilakukan pemilihan mesin yang sesuai agar dapat menggerakkan SPFB sesuai dengan kecepatan yang diinginkan. Mesin yang dipilih adlaah Yanmar 4LHA-STP dengan daya sebesar $230 \mathrm{HP}$.

\section{E. Perhitungan Trim}

Batasan trim menurut NCVS adalah Lpp/50, yakni sebesar $0.254 \mathrm{~m}$. Berikut adalah hasil rekapitulasi perhitungan dari Maxsurf Stability Enterprise.

Tabel 1.

Rekapitulasi perhitungan trim

\begin{tabular}{|c|c|c|c|}
\hline \multicolumn{4}{|c|}{ PERHITUNGAN TRIM } \\
\hline LOADCASE & $\begin{array}{c}\text { CONSTRAINT } \\
(\mathrm{m})\end{array}$ & $\begin{array}{c}\text { VALUE } \\
(\mathrm{m})\end{array}$ & STATUS \\
\hline LOADCASE 1 & 0.254 & 0.171 & Accepted \\
LOADCASE 2 & 0.254 & 0.137 & Accepted \\
LOADCASE 3 & 0.254 & 0.096 & Accepted \\
LOADCASE 4 & 0.254 & 0.096 & Accepted \\
LOADCASE 5 & 0.254 & 0.210 & Accepted \\
LOADCASE 6 & 0.254 & 0.229 & Accepted \\
LOADCASE 7 & 0.254 & 0.189 & Accepted \\
LOADCASE 8 & 0.254 & 0.152 & Accepted \\
\hline
\end{tabular}

\section{F. Perhitungan Stabilitas}

Perhitungan stabilitas dilakukan dengan bantuan software Maxsurf Stability Enterprise. Kriteria stabilitas yang digunakan dalam perhitungan adalah IS Code 2008 [5]. Berikut adalah hasil rekapitulasi perhitungan stabilitas berserta batasannya : 
Tabel 2.

Rekapitulasi loadcase 1 - loadcase 4

\begin{tabular}{|l|r|r|r|r|l|l|}
\hline \multicolumn{1}{|c|}{ Data } & $\begin{array}{c}\text { Loadcase } \\
\text { I }\end{array}$ & $\begin{array}{c}\text { Loadcase } \\
\text { II }\end{array}$ & $\begin{array}{c}\text { Loadcase } \\
\text { III }\end{array}$ & $\begin{array}{c}\text { Loadcase } \\
\text { IV }\end{array}$ & $\begin{array}{c}\text { Kriteria } \\
\text { IMO }\end{array}$ & Kondisi \\
\hline $\mathrm{e}_{0-30^{\circ}}(\mathrm{m} . \operatorname{deg})$ & 25.4833 & 25.4412 & 26.2207 & 26.2207 & $\geq 3.1513$ & Diterima \\
\hline $\mathrm{e}_{0-40^{\circ}}(\mathrm{m} \cdot \mathrm{deg})$ & 38.6057 & 38.5361 & 39.6007 & 39.6007 & $\geq 5.1566$ & Diterima \\
\hline $\mathrm{e}_{30-40^{\circ}}(\mathrm{m} . \mathrm{deg})$ & 13.1224 & 13.0949 & 13.38 & 13.38 & $\geq 1.7189$ & Diterima \\
\hline $\mathrm{h}_{30^{\circ}}(\mathrm{m} . \operatorname{deg})$ & 1.381 & 1.371 & 1.405 & 1.405 & $\geq 0.2$ & Diterima \\
\hline$\theta_{\max }(\mathrm{deg})$ & 53.6 & 53.6 & 50 & 46.4 & $\geq 25$ & Diterima \\
\hline $\mathrm{GM}_{0}(\mathrm{~m})$ & 1.206 & 1.125 & 1.153 & 1.153 & $\geq 0.15$ & Diterima \\
\hline
\end{tabular}

Tabel 3.

Rekapitulasi loadcase 5 - loadcase 8

\begin{tabular}{|l|r|r|r|r|l|l|}
\hline \multicolumn{1}{|c|}{ Data } & $\begin{array}{c}\text { Loadcase } \\
\mathrm{V}\end{array}$ & $\begin{array}{c}\text { Loadcase } \\
\mathrm{VI}\end{array}$ & $\begin{array}{c}\text { Loadcase } \\
\text { VII }\end{array}$ & $\begin{array}{c}\text { Loadcase } \\
\text { VIII }\end{array}$ & $\begin{array}{c}\text { Kriteria } \\
\text { IMO }\end{array}$ & \multicolumn{1}{|c|}{ Kondisi } \\
\hline $\mathrm{e}_{0-30^{\circ}}(\mathrm{m} \cdot \mathrm{deg})$ & 26.8876 & 26.925 & 27.7856 & 28.4593 & $\geq 3.1513$ & Diterima \\
\hline $\mathrm{e}_{0-40^{\circ}}(\mathrm{m} . \mathrm{deg})$ & 40.8412 & 40.8701 & 42.0778 & 42.9959 & $\geq 5.1566$ & Diterima \\
\hline $\mathrm{e}_{30-40^{\circ}}(\mathrm{m} . \mathrm{deg})$ & 13.9536 & 13.9451 & 14.2922 & 14.5366 & $\geq 1.7189$ & Diterima \\
\hline $\mathrm{h}_{30^{\circ}}(\mathrm{m} \cdot \mathrm{deg})$ & 1.471 & 1.464 & 1.485 & 1.501 & $\geq 0.2$ & Diterima \\
\hline$\theta_{\max }(\mathrm{deg})$ & 54.5 & 54.5 & 52.7 & 47.3 & $\geq 25$ & Diterima \\
\hline $\mathrm{GM}_{0}(\mathrm{~m})$ & 1.326 & 1.247 & 1.281 & 1.311 & $\geq 0.15$ & Diterima \\
\hline
\end{tabular}

\section{G. Perhitungan Freeboard}

SPFB ini menggunakan perhitungan lambung timbul dari NCVS (Non-Convention Vessel Standard) [3]. Berikut adalah hasil perhitungan lambung timbul SPFB :

Tabel 4.

Hasil perhitungan freeboard

\begin{tabular}{|l|c|c|}
\hline \multicolumn{1}{|c|}{ Lambung Timbul } & Nilai & Satuan \\
\hline Lambung Timbul yang Syaratkan & 0.35 & $\mathrm{~m}$ \\
Lambung Timbul Sebenarnya & 1.34 & $\mathrm{~m}$ \\
Kondisi & Diterima & \\
\hline
\end{tabular}

\section{H. Perhitungan Displacement}

Perhitungan displacement diperlukan untuk mengetahui apakah daya apung yang dihasilkan kapal sudah cukup untuk membuat kapal tersebut mengapung atau belum. Berikut adalah rekapitulasi perbandingan antara berat kapal LWT dan DWT dengan daya apung yang dihasilkan kapal

\section{Tabel 1.}

Hasil perbandingan displacement dan berat kapal

\begin{tabular}{|c|c|c|c|c|c|c|c|c|}
\hline \multicolumn{2}{|c|}{ BERAT TOTAL } & \multicolumn{4}{|c|}{ DISPLACEMENT } & \multirow{2}{*}{\multicolumn{2}{|c|}{ SELISIH }} & $\begin{array}{l}\text { CHECK } \\
\text { DISPIACEME }\end{array}$ \\
\hline \multirow[t]{2}{*}[\mathrm{kg}]{} & \multirow{2}{*}{$\begin{array}{c}\text { LCG } \\
{[\mathrm{m}]}\end{array}$} & \multirow{2}{*}{$\begin{array}{l}\text { VCG } \\
{[\mathrm{m}]}\end{array}$} & \multirow[t]{2}{*}[\mathrm{kg}]{} & \multirow{2}{*}{$\begin{array}{l}\text { LCB } \\
{[\mathrm{m}]}\end{array}$} & \multirow{2}{*}{$\begin{array}{l}\text { VCB } \\
{[\mathrm{m}]}\end{array}$} & & & $\begin{array}{l}\text { UISPLACEIVIE } \\
\text { NT }\end{array}$ \\
\hline & & & & & & {$[\mathrm{kg}]$} & $\%$ & \\
\hline 18412.87 & 0.220 & 0.806 & 19297.7 & 1.032 & 0.381 & 884.812 & $4.59 \%$ & Un \\
\hline
\end{tabular}

\section{Lines Plan}

Dalam proses desain SPFB, pembuatan rencana garis dengan menggunakan software Maxsurf Modeler. Pembuatan model dilakukan dari nol dengan patokan perkiraan berat kapal awal yang telah dihitung pada langkah sebelumnya. Kemudian direkayasa sedemikian rupa sehingga memenuhi semua persyaratan teknis, seperti rasio ukuran utama dan margin displacement.

Untuk melihat smooth atau tidaknya permukaan desain, didalam Maxsurf Modeler telah disediakan pandangan dari beberapa sudut, yaitu tampak depan/belakang, tampak samping, tampak atas dan pandangan perspektif. Garis-garis dari berbagai sudut pandang itulah yang nantinya akan dijadikan sebagai rencana garis.

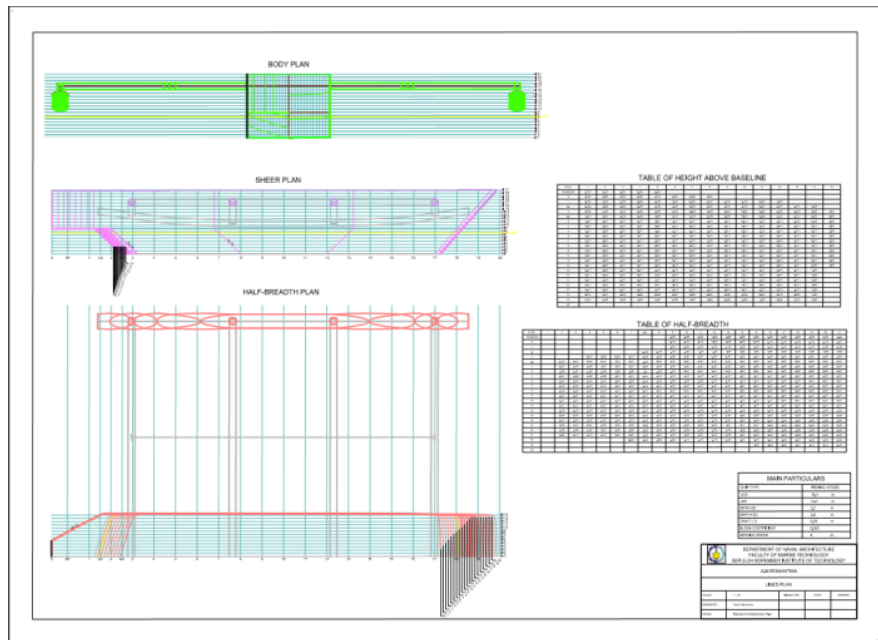

Gambar 5. Lines Plan SPFB

\section{J. General Arrangement}

Setelah pembuatan rencana garis selesai, langkah selanjutnya adalah membuat Rencana Umum / General Arrangement. Rencana umum didefinisikan sebagai perencanaan ruangan yang dibutuhkan sesuai dengan fungsi dan perlengkapannya.

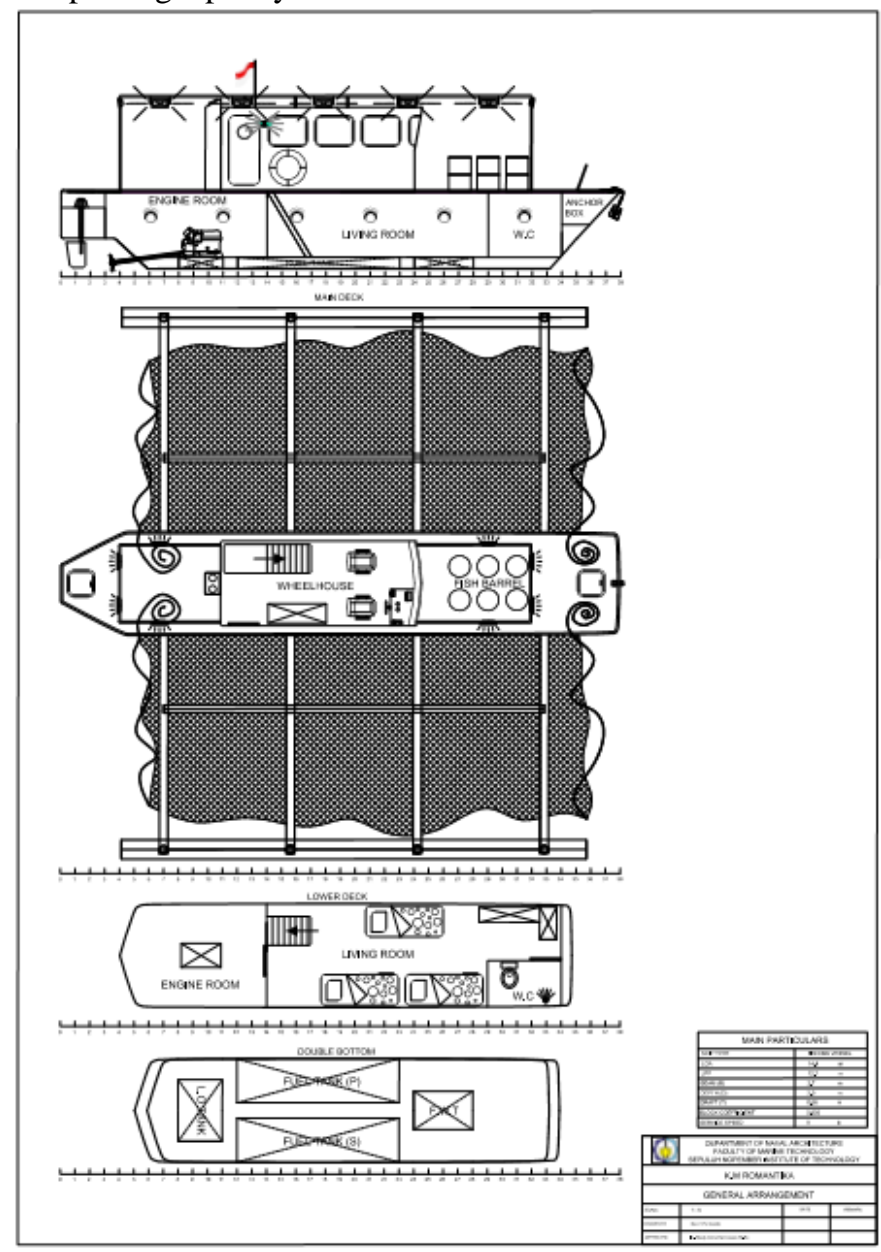

Gambar 6. General Arrangement SPFB 


\section{K. 3D Design}

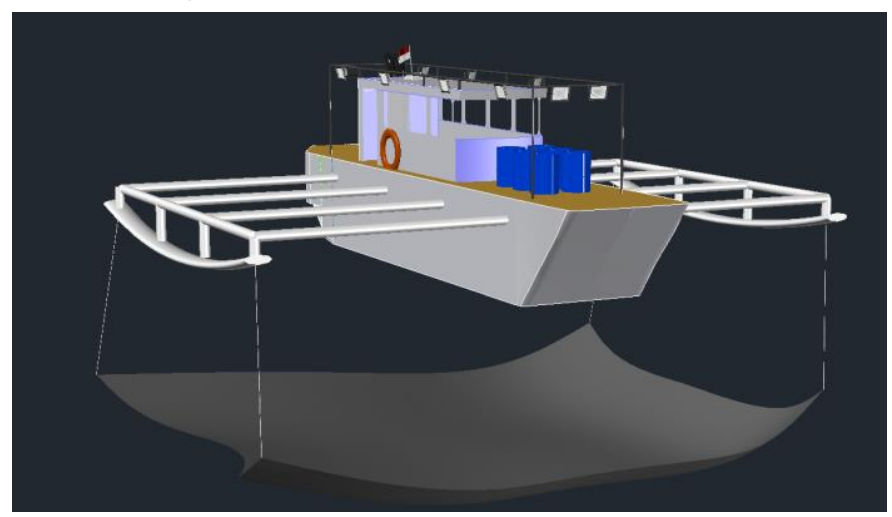

Gambar 7. 3D Design SPFB (1)

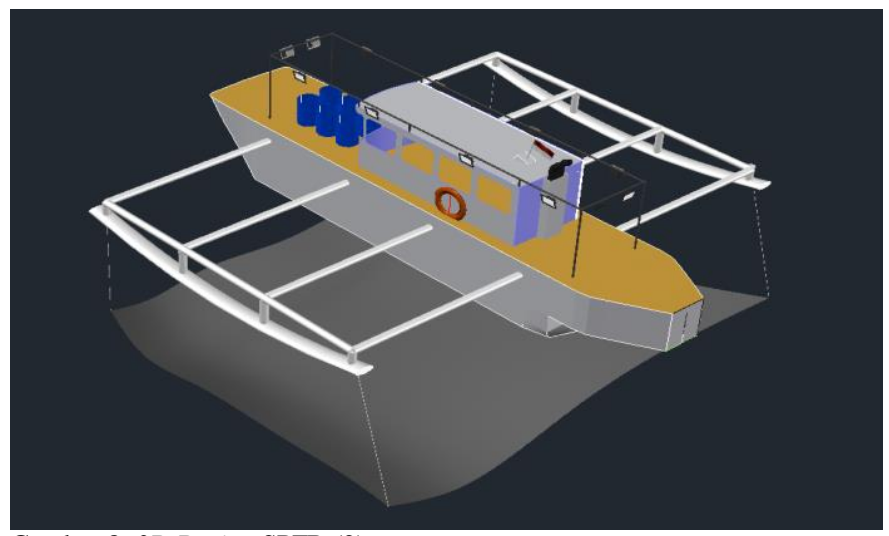

Gambar 8. 3D Design SPFB (2)

\section{ANALISIS EKONOMI SPFB}

\section{A. Biaya Pembangunan}

Total biaya pembangunan untuk lambung, peralatan, dan permesinan SPFB adalah sebesar Rp. 764.194.127,00.

\section{B. Biaya Operasional}

Total operasional SPFB adalah Rp. 707.139.580,46.

\section{Perhitungan Investasi}

Diasumsikan hasil tangkapan sebanyak 0.5 ton, pendapatan SPFB adalah Rp. 225.000.000,00 per bulan Sehingga, keuntungan bersih yang didapat tiap tahunnya adalah sebesar Rp 642.850.419,00 per tahunnya.

\section{Perhitungan BEP}

Pada perhitungan ini, terlihat bahwa BEP terjadi pada bulan ke-8. 8 bulan operasi SPFB atau sama dengan 1 tahun 2 bulan, karena dalam 1 tahun, SPFB hanya beroperasi selama 6 bulan.

\section{KESIMPULAN DAN SARAN}

Berdasarkan uraian dari tugas akhir ini, dapat disimpulkan bahwa

1. Material fiberglass tidak mencemari lingkungan. Sudah mulai bermunculan teknologi yang membuat fiberglass semakin ramah lingkungan.

2. Setelah dilakukan rekayasa, bentuk SPFB yang paling sesuai menghasilkan ukuran utama sebagai berikut :

- Lpp $($ Panjang $)=12,7 \quad \mathrm{~m}$
$\begin{array}{lll}-\mathrm{B}(\text { Lebar) } & =2,7 & \mathrm{~m} \\ -\mathrm{H}(\text { Tinggi) } & =2 \mathrm{~m} \\ -\mathrm{T} \text { (Sarat) } & =0,66 \quad \mathrm{~m}\end{array}$

3. Alat tangkap menggunakan waring angkat.

4. Lines Plan dan General Arrangement telah dibuat.

5. Biaya pembangunan SPFB sebesar Rp. 764.194.127,00 Estimasi keuntungan bersih per tahun operasi adalah sebesar Rp. 642.850.420,00 dan biaya operasional per tahunnya adalah Rp. 707.149.580,00. BEP terjadi dalam waktu 1 tahun 2 bulan.

6. Perhitungan teknis yang dilakukan telah memenuhi.

- Perhitungan berat yang telah dilakukan menghasilkan margin berat sebesar $4,59 \%$. Perhitungan berat diterima.

- Kondisi trim pada tiap loadcase sudah memenuhi persyaratan NCVS tahun 2009, yakni tidak boleh melebih Lpp/50.

- Perhitungan batasan lambung timbul sebesar $0,35 \mathrm{~m}$, sedangkan lambung timbul kapal sebenarnya adalah $1,34 \mathrm{~m}$. Sehingga perhitungan lambung timbul diterima.

- Hasil yang didapatkan semua parameter stabilitas telah terpenuhi.

7. Desain 3D telah dibuat dan terlampir.

Saran yang dapat diberikan adalah :

1. Perlu adanya tinjauan lebih rinci terhadap aspek konstruksi dan kekuatan Self-Propellef Fishing Barge.

2. Analisis lebih dalam mengenai sistem penangkapan SPFB dapat dijadikan rekomendasi untuk tema Tugas Akhir berikutnya.

3. Perlu dibuat permodelan $3 \mathrm{D}$ yang lebih presisi dan lebih mendetail terkait peralatan pelengkap di atas SPFB. Bila perlu menambahkan desain 3D interior untuk SPFB ini.

4. Serta diharapkan adanya perhitungan $\&$ analisis ekonomis yang riil terhadap anggaran pembangunan SPFB, sehingga SPFB ini dapat direalisasikan.

\section{DAFTAR PUSTAKA}

[1] NCVS, "Non-Convention Vessel Standard Indonesia Flagged Ch. $6, "$.

[2] Wikipedia, "Pengertian barge," Wikipedia, 2017. [Online]. Available: en.wikipedia.org/wiki/barge .

[3] Wikipedia, "Defisini kapal ikan," wikipedia, 2017. [Online]. Available: en.wikipeda.org/wiki/kapalikan .

[4] K. R. of S. (KR), Towing Arrangements and Resistance. Daejeon, 2010.

[5] I. S. (IS) Code, Intact Stability for All Types of Ships Covered by IMO Instruments Resolution A.749(18). Ch. III/3.5. 